\title{
Profile and Problem of Micro, Small and Medium Enterprises in Bandung
}

\author{
Suryanto \\ Department of Business Administration \\ Universitas Padjadjaran \\ Bandung, Indonesia \\ email:suryanto@unpad.ac.id
}

\author{
Herwan Abdul Muhyi \\ Department of Business Administration \\ Universitas Padjadjaran \\ Bandung, Indonesia \\ email: herwan_am@yahoo.com
}

\begin{abstract}
This research aims to explain the profile and problems of micro, small and medium enterprises (MSMEs) in Bandung. The research method used is qualitative with explorative research type. Primary data sources were obtained through indepth interviews and direct field observation. The secondary data sources are obtained from scientific articles, online publications, and documents related to the object of this study. The results showed that the proportion of micro, small and medium enterprises were $87.09 \%, 7.50 \%$, and $5.41 \%$, respectively. While the absorption rate of $73 \%$ micro employment, $22 \%$ small business and 5\% medium enterprises. MSMEs are divided into categories of fashion, food and beverages, handicrafts, services, and trade. The perpetrators of MSMEs are more dominated by men than women with the highest level of education from high school graduates. Meanwhile, most businesses are dominated by business groups with assets of between 50 and 500 million, while the highest sales turnover is between 10-50 million. The problem of MSMEs can be identified, among others: (1) lack of entrepreneurship spirit; (2) low human resources competency; (3) Limited access to funding; and (4) The absence of counterparts.
\end{abstract}

Keywords_-profile; MSMEs; problems; Bandung City

\section{INTRODUCTION}

Group of micro, small and medium enterprises (MSMEs) is a form of economic life of most people of Indonesia. The existence of this group cannot be separated from the national economic growth. The MSMEs Group according to BPS (2016) is able to absorb more than 64 million workforces and contributes approximately $58.2 \%$ to the formation of Gross Domestic Produk (GDP).

The existence of MSMEs according to Matambalya (2010) becomes an important issue as a motor of growth and economic growth in many countries in the world. High economic growth in many countries is a national economic performance supported by efficient, productive and highly competitive MSMEs.

According to the European Commission (2011) that the role of MSMEs in various parts of the world is very central to the growth and development of the national economy of a country. The same is true in the EU, that MSMEs significantly contribute to the economy of the country. The general contribution is in terms of labor absorption and in increasing GDP.
More specifically, we can see a significant role of MSMEs in the growth of the national economy in many European countries. The number of MSMEs in France reaches $99.80 \%$ of the total companies, contributing more than $56 \%$ of GDP and absorbing more than $61 \%$ of the workforce. MSMEs in Germany reached $99.55 \%$ with a contribution of $53 \%$ of GDP and absorb $61 \%$ of the workforce. MSMEs in Italy reach $99.92 \%$ with contribution $71 \%$ of GDP and absorb $81 \%$ of labor. While MSMEs in Nederlands reach $99,72 \%$ with contribution $62 \%$ of GDP and absorb $68 \%$ labor.

The same role of MSMEs also occurs in the United States which has more than $99 \%$ of MSMEs that can absorb more than $63 \%$ of the workforce. MSMEs in America play an important role in export performance, although in the mechanism of MSMEs do not do the direct export, but cooperation with multinational exporter company (The United States International Trade Commission, 2010). The same role also occurs in Canada, as Seen (2015) explains that exporting MSMEs have an important role in the economy, contributing to growth, productivity, and employment.

In addition to Europe and America according to Berry, et.al. (1991) that MSMEs in East and Southeast Asia countries such as Japan, Taiwan, South Korea and Singapore also have a central role in the development of their respective national economies. MSMEs in Indonesia also have an important role in the absorption of labor and in contributing to GDP. However, MSMEs in Indonesia according to Rizal (2014) still have some problems, such as financing, technology and product innovation, market research and inefficiency. Andang (2007) states that the problems of MSMEs can be grouped into three, among others: the problems that are classical and fundamental, advanced problems, and intermediate problems. Other problems, according to the results of the study of the Institute of Management, Faculty of Economics, University of Indonesia dictated by Sutrisno and Lestari (2009) include: bookkeeping issues, thin business margin, limited capital, limited managerial experience, economies too small, low, and the ability to obtain low funding sources. Meanwhile, according to Hermanto and Suryanto (2017), MSMEs will grow if supported by a good entrepreneurial ecosystem.

The problem of MSMEs in Indonesia is actually there are some ministries, local government and other institutions such as state-owned enterprises that have provided coaching and assistance. However, the guidance and assistance provided are not on target due to the lack of information on the profile and problems of each MSMEs. During this coaching and 
assistance provided still generalized to all MSMEs, so the results are not as expected.

The lack of data on the MSMEs profile becomes one of the weaknesses in making a policy. So far, the policy towards MSMEs is only used as a political commodity both at the central and regional levels. The existence of current MSMEs profile and problems is needed for policy makers to make policies appropriately.

\section{RESEARCH METHOD}

This research uses the descriptive method with a qualitative approach. Data collection was done by observation, in-depth interviews, and documentation study. Target research is directed to capture the identity data, characteristics, number, type of business, and problems faced by MSMEs actors. Sources of information in this study are the parties who have direct involvement with MSMEs. Data analysis is done by triangulation of source and data type. Interpretation is done refers to the theory, the results of previous research, the opinions of experts, and the sharpness of the researcher's thinking.

\section{RESUlt AND DISCUSSION}

Development of micro, small and medium enterprises (MSMEs) in the city of Bandung has a very strategic value in encouraging economic growth populist. So that will have a direct impact on economic growth in the city of Bandung. The number of MSMEs in Bandung continues to increase from year to year, both in terms of the number of business units, labor and the amount of investment.

Basically, MSMEs are one of the sectors that have enough role in developing the economy. Therefore, MSMEs in Bandung get serious attention from the local government. Attention from local government, among others, by creating a good climate for the development of MSMEs. This is evident in the year 2016 Bandung received Natamukti Nindya award as a city with the development of the best MSMEs in Indonesia from Indonesia Council for Small Business and the Ministry of Cooperatives and SMEs.

Characteristics of MSMEs is the nature or condition factual inherent in the business activity and behavior of the entrepreneur concerned in running the business. This characteristic is the distinguishing characteristic between business actors according to the scale of their business. According to the World Bank, MSMEs can be grouped into three types, namely: (1). Micro-enterprises (total of 10 employees); (2). Small business (number of employees 30 people); and (3). Medium enterprises (number of employees up to 300 people). While in the business perspective, MSMEs is classified into four groups, namely:

(1) MSMEs of the informal sector, for example, street vendors.

(2) Micro MSMEs are MSMEs with the ability of craftsmen but have the less entrepreneurial spirit to develop their business.

(3) Dynamic Small Business is a group of MSMEs capable of entrepreneurship by establishing cooperation (receiving subcontract work) and export.
(4) Fast Moving Enterprise is an MSMEs that has capable entrepreneurship and is ready to transform into a big business.

While the grouping of MSME according to Law Number 20 the year 2008 about MSMEs, among others:

(1) Micro enterprises shall be productive enterprises owned by natural persons and / or individual business entities that meet the criteria of micro business as regulated in this law.

(2) Small-scale business shall be a stand-alone productive economic enterprise, carried out by an individual or business entity which is not a subsidiary or not a branch of a company owned, controlled, or a part, directly or indirectly, of a medium-sized or large- meet the criteria of small-scale business as referred to in this law.

(3) Medium Enterprise shall be a stand-alone productive economic enterprise, conducted by an individual or business entity which is neither a subsidiary nor a branch of a company owned, controlled, nor a share either directly or indirectly with a small business or a large business by the amount net worth or annual sales proceeds as provided in this Law.

\section{A. Profile of MSMEs Bandung}

MSMEs Profile in this research presents data and information on business actors in general in Bandung. MSMEs in Bandung according to data as of December 2015 amounted to 5,198 with the composition as in Graph 1 .

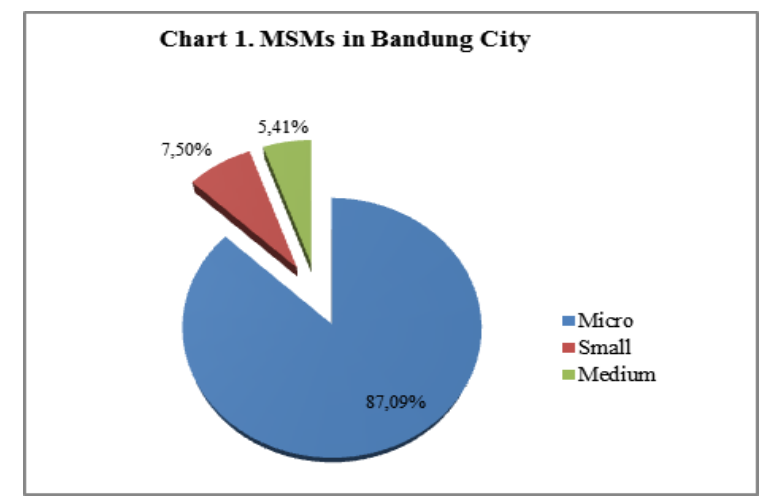

Based on Graph 1 above, most business groups are micro businesses. This business group continues to increase every year, while small and medium businesses are relatively stable despite the relatively small increase in numbers. Increasing the number of MSMEs in the city of Bandung need to get serious attention from the Government of Bandung in order to increase the number of MSMEs can provide benefits both in economic growth and employment. The number has increased from previous years. The highest increase occurred in the small-scale business sector which increased by $29.57 \%$ compared to the previous 5 years, followed by a microbusiness which reached $24.06 \%$. While the middle business sector only increased by $3.69 \%$.

The number of MSMEs can be grouped into groups of fashion, food and beverage, service, and trade. The following data per industry group can be seen in Graph 2 . 


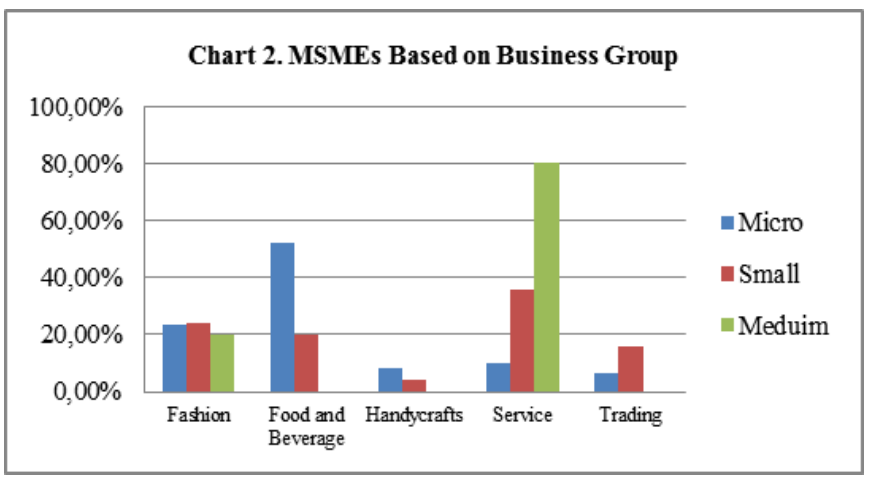

Based on Graph 2 above, it can be seen that most of the business group in the micro business group is in food and beverage sector, the small business group is in the service sector, and the medium business group is in the services sector. While business groups that do not have a group win are the food and beverage sectors, services and trade. Food and beverage sector became the most rapidly growing microbusiness group because Bandung became a tourist destination visited by many domestic and foreign tourists.

When viewed from the sex, entrepreneurs belonging to MSMEs are dominated by men. However, although there are more men, women's groups are also relatively large. Here is the composition of the perpetrators of MSMEs in Bandung according to gender.

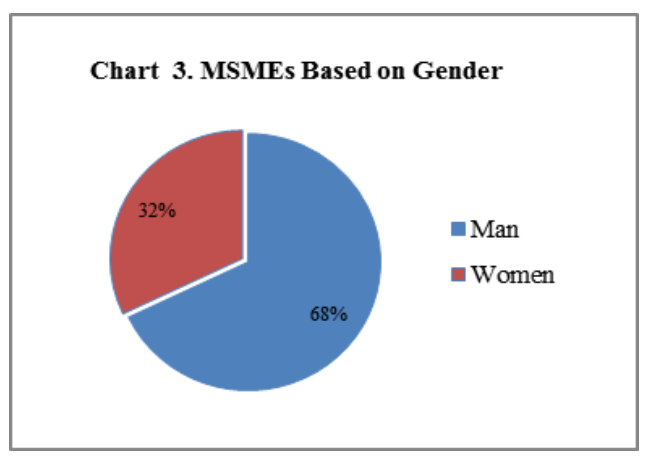

Based on Graph 3 above, there are more male businessmen compared to women. The male group is $68 \%$, while the female group is $32 \%$. Meanwhile, the perpetrators of MSMEs when viewed from the level of education can be seen in Graphic 4 below.

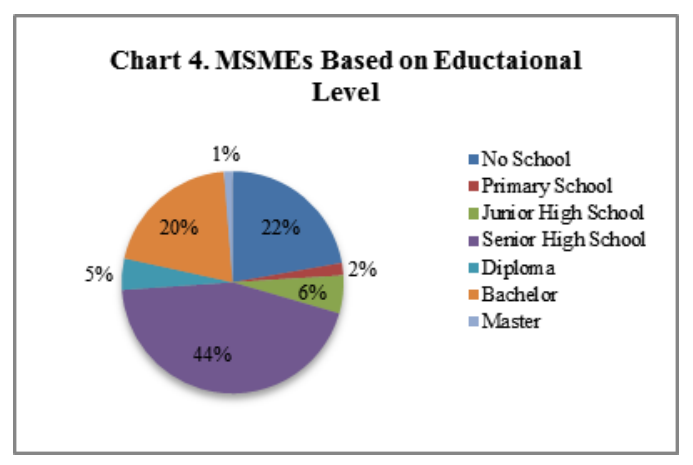

Based on Graph 4 above, it is seen that the level of education of entrepreneurs belonging to the MSME group is dominated by $43 \%$ of high school graduates, followed by nonschool groups $23 \%$ and $20 \%$ for undergraduate graduates. While graduates from elementary, junior and senior high schools are each under $6 \%$

When viewed from the ability to absorb labor, the MSMEs in the city of Bandung more dominated by business groups that have a workforce of 5 people. The following groups of MSMEs when viewed from the ability to absorb labor.

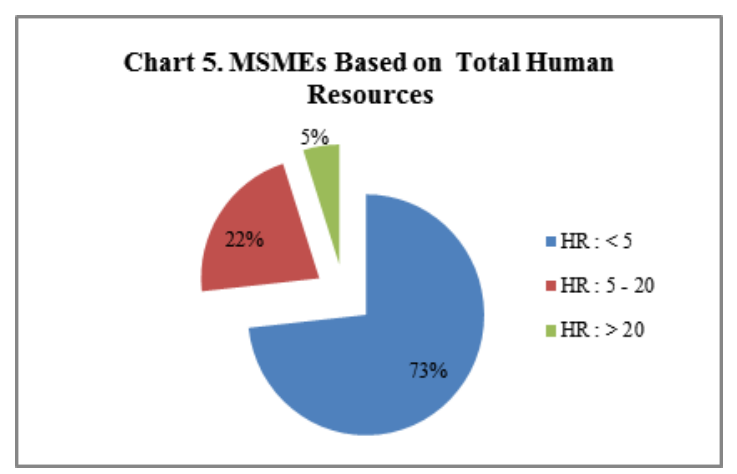

Based on Graph 5 above shows that MSMEs with fewer than 5 employees are the largest group with a percentage of $73 \%$, while MSMEs are able to absorb labor between 5-20 people as much as $22 \%$, the remaining $5 \%$ of MSMEs are able to absorb energy work more than 20 people. Most MSMEs are only able to absorb the workforce of fewer than 5 people because most MSME groups exist in the micro business group.

When viewed from the composition of assets owned, MSMEs can be grouped into assets of less than 50 million, 50 million to 500 million, 500 million-1 billion, and business groups that have assets of more than 1 billion. In Graphic 6 below, the composition of firms with varying assets is shown.

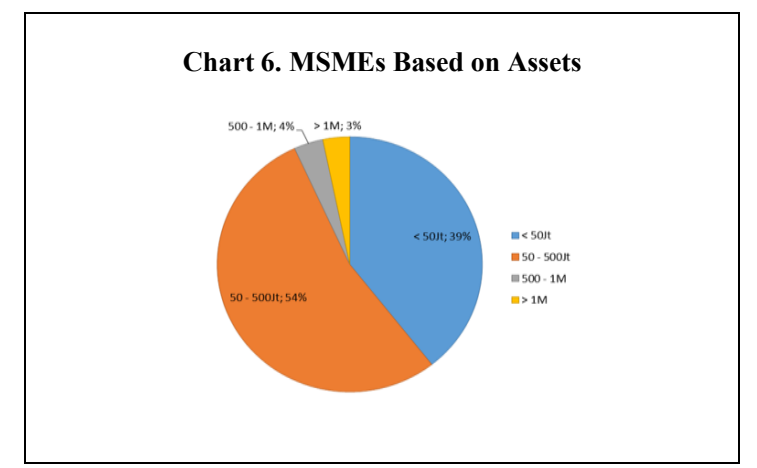

Based on Graph 6 above, the largest business type is a group of businesses with assets of between 50 and 500 million, while the group with the least assets is a business group with assets above 1 billion that is only $3 \%$.

When viewed from the turnover of sales per year, MSMEs can be grouped into business groups with a turnover of less than 10 million, 10-50 million, 50-250 million, and more than 250 million. The following is the distribution of companies based on turnover per month. 
Chart 7. MSMEs Based on Omzet

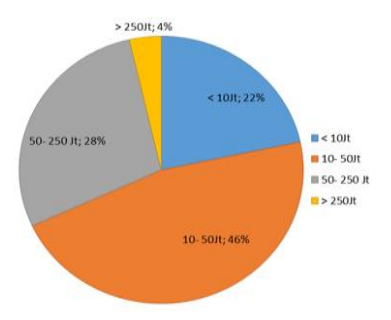

Based on Graph 7 above, the most business groups are those with an annual turnover of between 10-50 million. This business group dominates the composition by a percentage of $46 \%$ and belongs to the micro business group. While the business group with the smallest percentage that is only $4 \%$ is the business group which has annual sales turnover above 250 million.

\section{B. Problems Faced by MSMEs in the City of Bandung}

MSMEs in the city of Bandung growth continues to grow especially in the category of micro-enterprises. However, the development of micro-business is not followed by the development of small and medium enterprises. Small and medium-sized businesses are relatively stagnant, although there are relatively small developments in small businesses. The market structure facing micro-enterprises leads to perfect competition (many producers and many consumers), the level of competition is very tight. As a result, the bankrupt or out of the business arena is relatively large, but new players who enter even more, so the number of micro business continues to grow although the perpetrators change.

The problem that always faced on the perpetrator of MSMEs was not only in the capital sector. This shows that the factor of business capital for MSMEs is not the only problem faced. The results of this study are in accordance with the proposed Tambunan (2009) which states that although capital flows quite a lot to MSMEs, if not followed by coaching, especially about how to use the aid received then MSMEs will tend to be unsuccessful.

Here are some of the problems that are often faced by MSMEs in Bandung that can be identified, among others:

\section{1) Less Have Entrepreneurship Soul}

People who have an entrepreneurial spirit are people who have creative and innovative ability that can be used as a basis, tips or resources to look for opportunities to succeed. The point is people who have the ability to create something new and different through creative thinking and innovative action to create opportunities. So that person who has this soul, he will always be energetic, creative and innovative on the move.

Most micro MSMEs do business because they follow the current trend. They open a business because they are interested in seeing the success of other people's business, without any element of their own creativity. So that when there is a slight resistance they immediately stop not continue his business.

\section{2) Competence of Human Resources Low}

MSMEs are less knowledgeable about the latest aspects of production technology and how to run quality control of the product. The ability to read the market needs is still not sharp, so it has not been able to capture carefully the needs of the market. Product marketing still relies on the simple mouth to mouth marketing. Has not made social media or internet network as a marketing tool.

Low human resource competencies also appear in their inability in financial aspects, especially in terms of finding and managing finances as well as bookkeeping practices. In addition, less competence is also in the managerial aspect. They lack strategic thinking because they are still often involved in technical issues. This is in accordance with the research Hermanto and Suryanto (2017) that entrepreneurial human resources are still low.

\section{3) Limitations on Access to Funding}

Most MSMEs have not been touched by the services of formal financial institutions (banks). This happens because of several factors, among others: (1) The existence of geographic barriers; (2) administrative obstacles of MSMEs actors, even though their business is feasible but not bankable; (3) Limited financial literacy level of MSMEs actors is minimal. They do not understand a number of financial products offer financial institutions. The existence of these constraining factors that cause MSMEs perpetrators is forced to utilize the services of traditional micro-finance institutions - although with burdens and risks are quite burdensome - in order to maintain the viability of its business.

The inability or absence of access for MSMEs to the financial institutions in obtaining information about capital causes MSMEs difficulty in increasing their business capacity or developing competing products.

\section{4) The absence of Mentoring Personnel}

Mentoring personnel is needed by the perpetrators of MSMEs in running the company's operations. They function to provide consultation services both in aspects of production, marketing, human resources development and in financial management. The counselor should be prepared by the government so as not to become a burden for the perpetrators of MSMEs.

\section{CONCLUSION}

MSMEs is a business sector capable of contributing to the Government of Bandung in the form of employment. This business group is dominated by micro business with the percentage of $87,09 \%$. While the small and medium business group each only $7.5 \%$ and $5.41 \%$. MSMEs in the city of Bandung can be grouped into a group of business fashion, food and beverage, service, and trade. Food and beverage sector became the most rapidly growing micro-business group because Bandung became a tourist destination visited by many 
domestic and foreign tourists. The perpetrators of MSMEs in the city of Bandung is dominated by men with the highest level of education from high school graduates. The business group that absorbs the most labor is in the business group with employees less than 5 people. Then when viewed from the total assets, the largest MSMEs that is equal to $73 \%$ owned business group with assets between 50 - 500 million with annual sales turnover of 10-50 million.

There are several problems that often hamper the development of SMEs, among others: (1) lack of entrepreneurship spirit; (2) low human resource competencies; (3) Limited access to funding; and (4) The absence of coworkers.

\section{ACKNOWLEDGMENT}

Directorate of Research, Technology and Community Service at the Ministry of Research, Technology and Higher Education, Republic of Indonesia.

\section{REFERENCES}

[1] Andang Setyobudi, Peran Serta Bank Indonesia Dalam Pengembangan Usaha Mikro, Kecil Dan Menengah (UMKM), Buletin Hukum Perbankan Dan Kebanksentralan, Volume 5, Nomor 2, Agustus 2007.

[2] Badan Pusat Statistik. Statistik Indonesia, Jakrta: BPS, 2016.
[3] Berry, Albert \& D. Mazumdar, Small-Scale Industry in the AsianPacific Region, Asian-Pasific Economic Literature, 1991.

[4] European Commission.. Third Annual Report on Implementation of the European Fisheries Fund , 2011

[5] Hermanto, Bambang \& Suryanto. Entrepreneurship Ecosystem Policy in Indonesia, Mediterranean Journal of Social Science, 2017, Vol. 8 No. 1 , p.110-115.

[6] Matambalya, Francis A.S.T., Profile of Small and Medium Scale Enterprises (SMEs) in the SADC Economies. Center for Development Research, Bonn University http://www.wipo.int/export / sites/www/about-ip/en/studies/pdf/study_f_matambalya.pdf

[7] Rizal, Empat kendala penghambat pengembangan UMKM, http://www.kabarbisnis.com/read/ 2845011, 2014.

[8] Seens, Daniel, SME Profile: Canadian Exporters, Small Business Branch Research and Analysis Directorate. https://www.ic.gc.ca/eic/site/061.nsf/vwapj/SMEPCEPPMEEC_2015_eng.pdf/\$file/ SMEPCE-PPMEEC_2015_eng.pdf, 2015.

[9] Sutrisno, Joko \& Lestari, Sri, Kajian Usaha Mikro Indonesia, Jurnal Pengkajian Koperasi dan UKM Nomor 2 Tahun I-2006.

[10] Tambunan, Tulus., UMKM Di Indonesia, Bogor: Ghalia Indonesia, 2009.

[11] United States International Trade Commission. ASEAN: Regional Trends in Economic Integration, Export Competitiveness, and Inbound Investment for Selected Industries. Washington. USITC Publication, 2010.

[12] Undang-Undang Republik Indonesia Nomor 20 Tahun 2008 Tentang Usaha Mikro, Kecil, dan Menengah 